LWSA

PAPER - OPEN ACCESS

\title{
The Application of Feminism in Minangkabau Matrilineal System
}

\author{
Author : Multhahada Ramadhani Siregar et al. \\ DOI $\quad: 10.32734 /$ lwsa.v3i4.1141 \\ Electronic ISSN $\quad: 2654-7066$ \\ Print ISSN : $2654-7058$
}

Volume 3 Issue 4 - 2020 TALENTA Conference Series: Local Wisdom, Social, and Arts (LWSA)

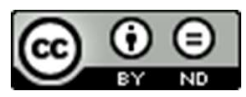

This work is licensed under a Creative Commons Attribution-NoDerivatives 4.0 International License.

Published under licence by TALENTA Publisher, Universitas Sumatera Utara

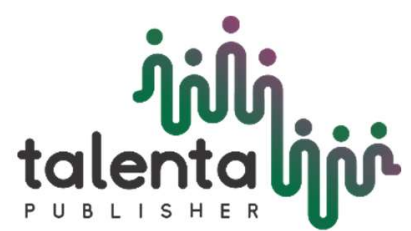




\title{
jibli talentalioำ TALENTA Conference Series

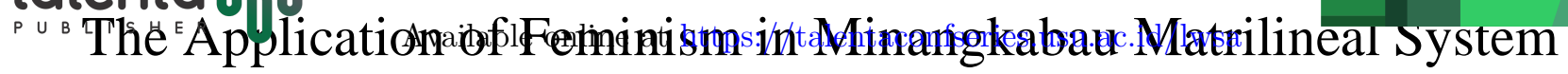

\author{
Multhahada Ramadhani Siregar ${ }^{a}$, Sitti Rahma ${ }^{a}$, Alemina Br. Perangin-angin ${ }^{a}$ \\ ${ }^{a}$ University of Sumatera Utara, Jalan Dr. Mansyur, Medan, 20155, Indonesia
}

multahadasiregar@gmail.com,rahmasittir@gmail.com, aleminaperanginangin@gmail.com

\begin{abstract}
This qualitative research is about how Minangkabau people apply feminism in their matrilinealism system. Feminism which is known as an ideology that defends the equality of right between woman and man in social life when mostly men have the role in many sectors. Minangkabau people believe woman has important role in social life. It can be seen on how they use proverb in their daily life. Proverb is commonly used by Minangkabau people in order to deliver the message or indirect expression in daily activity. This study analyzes the proverbs which express the role of women in Minangkabau. In this study, the researchers use Haley's theory on analyzing the proverbs that use metaphor as the figurative language and classifying them into nine types based on the semantic field. The objectives study of this research are (1) to identify Minangkabau proverbs about the role of woman, (2) to identify the types of metaphor in Minangkabau proverbs, (3) to describe feminism that applied in Minangkabau matrilinieal system. This study results feminism also applied in Minangkabau in the matrilinealism system. Minangkabau applies that women have equal right and access to opportunites in the society. However there are three positions that woman is not al lowed in Minangkabau, such as Manti (a tribe leader), Malin (a religion leader), and Dubalang (a leader of tribe safety).
\end{abstract}

Keywords: feminism; minangkabau; matrilinealism; metaphor

\section{Introduction}

Feminism is an ideology that seeks the equality of rights for women and men. Equality here does not mean "sameness" but the issue is about equal rights and equal access to opportunities. According to Sara Mills (1995) stated that most feminists hold a belief that women as a group are treated oppresively and differently from men and that they are subject to personal and institutional discrimination. Feminists also belive that society is organized in such a way that it works, in general, to the benefit of men rather than women; that is, that it is patriarchal. Thus, feminist research aims to be accessible, to enable others, to equip women with the skills and knowledge they need or want (Bowles and Klein 1983; Stanley 1990).

Based on the understanding above, this belief is also applied in one of Indonesian tribes, Minangkabau. Minangkabau applies that women have equal right and access to opportunites in the society as well as men. In the discussion "Memahami Sistem Matrilineal Minangkabau" in 25 December 2007, Dr. Raudha Thaib (West Sumatera Humanist) said," "Di Minangkabau, perempuan diperbolehkan untuk memasuki wilayah publik. Perempuan Minang tidak dikurung di rumah dan hanya berkecimpung di sektor domestik saja. Perempuan memegang peranan dalam pengambilan keputusan politik dalam kaum/suku dan diperbolehkan untuk menduduki jabatan publik. Dalam sejarah, Kerajaan Minangkabau pernah dipimpin oleh raja Perempuan, yang bernama "Bundo Kanduang". Hanya tiga posisi yang tidak boleh ditempati perempuan, yaitu Manti (pemimpin adat), Malin (pemimpin agama), dan Dubalang (pemimpin keamanan suku). "( In Minangkabau, a woman is allowed to be involved in public society. A Minangkabau woman is not trapped in the house and only involved in domestic sector. A woman holds important role in decision taking of politics in society and is allowed to hold public position. In the history, Minangkabau kingdom has led by a woman, which is called Bundo Kanduang. There are only three positions that woman are not allowed to be involved, such as Manti (a tribe leader), Malin (a religion leader), and Dubalang (a leader of tribe safety)).

Minangkabau people use proverb to deliver the message or commonly use indirect expression to deliver the idea in daily activity. Errington (2006: 74) said that one of the characteristics Minangkabau people is they do not frankly express their mind. So that, Minangkabau people mostly use figurative language which has indirect meaning. One of figurative languages that is used by Minangkabau people is metaphor. According to Kridalaksana (2008: 152)," Metafora adalah pemakaian kata atau ungkapan lain untuk objek atau konsep lain berdasarkan kias atau persamaan." (Metaphor uses word or other expression to identify the object or other concept based on the comparison or the similarity.) Haley (1989: 155-159) divides metaphor into nine types based on the semantic field, they are:

a. Metafora ke-ada-an (being) yaitu metafora yang meliputi hal-hal abstrak seperti kebenaran dan kasih.

b. Metafora kosmos (cosmos) yaitu metafora yang meliputi benda-benda kosmos misalnya matahari dan bulan.

c. Metafora tenaga (energy) yaitu metafora dengan medan semantik hal-hal yang memiliki kekuatan, misalnya angin, cahaya, api, dengan prediksi dapat bergerak.

d. Metafora substansi (substance) yaitu metafora yang meliputi macam-macam gas dengan prediksinya dapat memberikan kelembaban, bau, tekanan dan sebagainya.

(c) 2020 The Authors. Published by TALENTA Publisher Universitas Sumatera Utara

Selection and peer-review under responsibility of International Seminar on Languages,Cultures, and History 2020

p-ISSN: 2654-7058, e-ISSN: 2654-7066, DOI: 10.32734/lwsa.v3i4.1141 
e. Metafora permukaan bumi (terrestrial) yaitu metafora yang meliputi hal-hal yang terikat atau terbentang di permukaan bumi misalnya sungai, laut, gunung dan sebagainya.

f. Metafora benda mati (object) adalah metafora yang meliputi benda-benda yang tak bernyawa misalnya meja, buku, kursi, gelas dan sebagainya yang bisa hancur dan pecah.

g. Metafora tumbuhan (living) yaitu metafora yang berhubungan dengan seluruh jenis tumbuh-tumbuhan (flora) seperti daun, sagu, padi dan sebagainya.

h. Metafora binatang (animate) adalah metafora yang berhubungan dengan makhluk organism yang dapat berjalan, berlari, terbang dan sebagainya misalnya seperti kuda.

i. Metafora manusia (human) adalah metafora yang berhubungan dengan makhluk yang dapat berpikir dan mempunyai akal

In this study will analyze the use of metaphor in Minangkabau proverb which has meaning about the role of woman in Minangkabau. The objectives of this study are (1) to identify Minangkabau proverbs about the role of woman, (2) to identify the types of metaphor in Minangkabau proverbs, (3) to describe feminism that applied in Minangkabau matrinelial system.

\section{Literature Review}

Minangkabau is one of Indonesian tribes which applied matrilinealism system or the kinship or the tracing of kinship through the female line. Minangkabau people believe that woman has important role in social life. It can be analyzed in Minangkabau proverb which commonly used in their daily activity. One of researches that analyzes the role of woman in Minangkabau is Citra Perempuan Dalam Peribahasa Minangkabau by Gusna Ronsi. The researcher has a thought that Minangkabau women have important role and special. It is caused Minangkabau belives matrilineal system which the kinship based on the mother or the female line. In Minangkabau, woman symbolyzes bundo kanduang which means central figure in a family. The result of this research is concluded that there are several Minangkabau proverbs portray a woman symbolyzes firm and gentle, polite, consistent, wiseful, diligent, and wary.

The study of woman in Minangkabau also can be found in Kesetaraan Dan Keadilan Gender Dalam Adat Minangkabau by Rahima Zakia. In this research, Minangkabau has important value in gender equality by giving the value of rights and obligations also responsible between male and female based on the state and function in family, society, as well as government. In Minangkabau, woman is symbolyzed as Bundo Kanduang which has important role of the main source and decision taker.

In this study, the role of woman will be discussed on feminism perspective which is known as an ideology from western that defends the right of woman in society. By analyzing the proverb which commonly used symbolyzed how the Minangkabau people see the role of Minangkabau women.

\section{Research Method}

The methodology of this research employs qualitative method which is used in order to explain and describe the data. According to Bungin (2001:124 - 125), 'Data kualitatif diungkapkan dalam kalimat serta uraian-uraian, bahkan dapat berupa cerita pendek" (Qualitative data is applied in sentence and description, even in short story.) The next method which was used is descriptive method. Fraenkel and Wallen (1993:23) state that descriptive method is used to explain, analyze, and classify something through various techniques, survey, interview, questionnaire, and test.

\section{Discussion}

The following list below is Minangkabau proverb about the role of a Minangkabau woman which are classified based on the type of metaphor.

1. Human metaphor

Human metaphor compares the subject metaphor with human beings which have feelings and thoughts. Minangkabau proverb which has this metaphor type, such as:

- Amban puruak pagangan kunci

'treasurer holds the key'

Amban puruak means the role of a woman in Minangkabau as a treasurer belongs to her society. She controls the family finance in order to fullfil the family needs. This metaphor compares between a woman and treasurer or amban puruak. It relates woman and treasurer to express that the role of woman is important in Minangkabau society in economic aspect.

- $\quad$ Auih tampek minta aie

'when in thirst asked for water'

Lapa tampek minta nasi 
'when in hunger asked for rice'

tampek minta aie and tampek minta nasi describe the human's activity to give the human in thirst and hunger.

These comparisons express the relation between woman as the source of drink and food. It believes woman also has responsible in kitchen actvity to fullfil the food and drink for her family.

2. Animate metaphor

Animte metaphor compares every creature acts as if animal which has capibilty to walk, run, fly, etc. Minangkabau proverb which has this metaphor type, such as:

- limpapeh rumah nan gadang

'a butterfly in a big house'

This proverbs compares between limpapeh or a butterfly and a woman. This metaphor expresses that a woman has beautiful look but weak as butterfly. However, the woman has the power to watch and manage the people around her house especially her children. In Minangkabau matrilinealism believes that a woman deserves for the big house or rumah gadang that will be given to her children.

3. Object metaphor

Object metaphor compares unliving things, such as glass, chair, table, paper, etc which can be broken. Minangkabau proverb which has this metaphor type, such as:

- Kaunduang-unduang ka Madinah

'a head cover to Madinah'

Ka payuang panji ka Sarugo

'an umbrella to heaven'

The metaphor above describe two objects 'a head cover' and 'an umbrella' to compare the role of woman in Minangkabau as a protector. These objects express the function of 'a head cover' and 'an umbrella' is to protect something important that is 'the head'. Therefore, the comparison between these two objects and the role of Minangkabau woman is Minangkabau woman has the role to protect her family.

- Pusek jalo kumpulan tali

'the net center in rope ties'

Pusek jalo compares to the role of a Minangkabau woman as the center of every aspect. A Minangkabau woman has the central role to manage her family whether as a wife, a mother, and a part of her society that involved.

- Hiasan dalam nagari

'Jewellery in country'

Hiasan or jewellery symbolizes beauty, glory, charm. It compares to the role of woman in Minangkabau that beautiful but has elegancy in the society.

4. Energy metaphor

Energy metaphor compares the object to the energy thing, such as wind, fire, hot, light, etc. Minangkabau proverb which has this metaphor type, such as:

- Nan gadang basa batuah

'the great which is sacred'

Gadang basa batuah or 'the great which is sacred', this proverb symbolizes a Minangkabau woman as the great and sacred figure. The comparison expresses that a Minangkabau woman is someone who is respected. A woman in Minangkabau has the equality as man to give a vote in traditional conference.

5. Being metaphor

Being metaphor compares the object to the abstract noun which can not be identifiead by human phisically, such as love, sorrow, sad, anger, etc. Minangkabau proverb which has this metaphor type, such as:

- $\quad$ sumarak di dalam kampuang

'glory in village'

Sumarak in this concept is something can not be identified phisically but exist. It symbolizes wonderful, cheerful, luxurious, etc. It compares to the role of a Minangkabau woman that enlivens the society in case of the matrilinealism. A birth of a daughter in a minangkabau family is expected because the daughter will continue the descent.

\section{Conclusion}

Feminism an ideology that seeks the equality of rights for women and men. Equality here does not mean "sameness" but the issue is about equal rights and equal access to opportunities. This belief also applied in one of Indonesian tribes, Minangkabau in the matrilinealism system. Minangkabau applies that women have equal right and access to opportunites in the society. However there are three positions that woman is not allowed in Minangkabau, such as Manti (a tribe leader), Malin (a religion leader), and Dubalang (a leader of tribe safety). It can be seen in Minangkabau proverb that express the role of woman in Minangkabau. 


\section{References}

[1] Amir. 2007. Adat Minangkabau: Pola Tujuan Hidup Orang Minang. Jakarta: PT Mutiara Sumber Widya.

[2] Bungin, Burhan. 2001. Metodologi Penelitian Kualitatif Dan Kuantitatif. Yogyakarta:Gajah Mada Press

[3] December 2016. Revitalisasi Nilai-Nilai Budaya Perempuan Dalam Pepatah Adat Minangkabau. Retrieved from: http://retyaelsivia.blogspot.com/2016/12/revitalisasi-nilai-nilai-budaya.html?m=1. (March 2020)

[4] Fraenkel, J. R. and Wallen, N. G. 1993. How to Design and Evaluate Research in Education (2nd Ed.). New York: Mc. Graw-Hill International Edition.

[5] Haley, Michael C. 1980. 'Concrete Abstraction: The Linguistics Universe of Metaphor' dalam Marvin K. Ching dan Michael Haley. 1980. Linguistics Perspectives on Literature. London: Routledge \& Kegan Paul.

[6] January 2008. Feminisme pada Masyarakat Matrilineal Minangkabau. Retrieved from https://grelovejogja.wordpress.com/2008/01/08/feminisme-padamasyarakat-matrilineal-minangkabau/. (March 2020)

[7] Kridalaksana, Harimurti. 2008. Kamus Linguistik. Jakarta: Gramedia Pustaka Utama.

[8] Mills, Sara. 1995. Feminist Stylistics. Taylor and Francis: Sheffield.

[9] Oktavianus. 2006. Analisis Wacana Lintas Bahasa. Padang: Andalas University Press.

[10] Ronsi, Gusna. 2011. Citra Perempuan Dalam Peribahasa Minangkabau. Jurnal Ilmu Sosial dan Humaniora. 2011 April, 39 - 58.

[11] Zakia, Rahima. 2011. Kesetaraan dan Keadilan Gender Dalam Adat Minangkabau. Kafa'ah Journal of Gender Studies. 2011, 39 - 52. doi: $10.15548 /$ jk.v1i1.39 